\title{
An Association between Anti-Phospholipid Antibodies and Connective Tissue Diseases
}

\author{
Ketha Ravindra Reddy ${ }^{1}$, V. S. Sai Lakshmi ${ }^{2}$ \\ ${ }^{1}$ Professor, Department of Dermatology \& Venerology, Rajshree Medical College, Bareilly, U.P., ${ }^{2}$ Associate Professor, Department of General Medicine, Siddartha \\ Medical College, Vijayawada, A.P.
}

\section{Abstract}

Background: Anti-phospholipid antibodies (APLA) are mostly directed against phospholipids and also with their binding proteins. They are frequently associated with connective tissue disorders. Systemic Lupus Erythematosus (SLE) associated with APLA might cause diagnostic dilemma due to several manifestations mainly neurological, serositis proteinuria, thrombocytopenia, haemolytic anemia, ulceration of legs, which occur in both the conditions. So, we had conducted a study to determine the association between anti-phospholipid antibodies and connective tissue diseases and also compared clinical and laboratory parameters between anti-phospholipid antibody positive and antiphospholipid antibody negative groups. Subjects and Methods: The present study was conducted among two hundred and four patients who were diagnosed with connective tissue diseases. APLA testing was done at baseline and the patients who were found to be positive for the test, a repeat of the test was performed after 12 weeks. Results: Among the patients with connective tissue diseases (14 p.c) had a positive test result for anti-phoshpolipid antibodies. In the SLE group positive anti-phospholipid antibody was detected among 73.3 p.c of patients, mixed connective tissue disease (MCTD) was present among 13.3 p.c of the patients and systemic sclerosis was present among 13.3 p.c of the patients. Conclusion: Always an anti-phospholipid antibody test should be conducted among all the patients with connective tissue disease for early diagnosis and prevention of life-threatening complications.

Keywords: Anti-phospholipid antibodies, Connective tissue disease, SLE.

Corresponding Author: Dr. V.S. Sai Lakshmi, Associate Professor, Department of General Medicine, Siddartha Medical College, Vijayawada, A.P.

Received: September 2019

Accepted: September 2019

\section{Introduction}

Anti-phospholipid antibodies (APLA) are the heterogeneous family of plasma autoantibodies which recognize the antigenic epitopes carried by phospholipoproteins. ${ }^{[1]}$ Antiphospholipid antibody syndrome (APS) is a thrombotic disorder, defined by the presence of one (or) more clinical features of thrombosis and presence of anti-phospholipid antibodies (APLA) such as anti-cardiolipin (aCL), antib2GP1 and lupus anticoagulant (LA). ${ }^{[2,3]}$ APS is mostly associated with an underlying autoimmune disorder such as Systemic Lupus Erythematosus (SLE), the underlying disorder is not identified in primary APS. ${ }^{[4,5]}$ Antiphospholipid antibody (APLA), which occur secondary to Systemic Lupus Erythematosus (SLE) and other autoimmune diseases is termed as secondary antiphospholipid antibody syndrome which is characterized by arterial and venous thrombosis, recurrent miscarriages during pregnancy and neurological manifestations.6 APLA are prevalent in patients with SLE (50 p.c) with LA (15-34 p.c) and aCL (12-30 p.c) approximately.7 Systemic Lupus Erythematosus (SLE) associated with APLA might cause diagnostic dilemma due to several manifestations mainly neurological manifestations, serositis proteinuria, thrombocytopenia, haemolytic anemia, ulceration of legs, which occur in both the conditions.8 Due to the presence of less number of studies, we had planned to conduct a study to determine the association between anti-phospholipid antibodies and connective tissue diseases and also compared clinical and laboratory parameters between antiphospholipid antibody positive and anti-phospholipid antibody negative groups.

\section{$\underline{\text { Aim \& Objectives }}$}

1. To determine various aetiologies associated with connective tissue diseases.

2. To estimate the connective tissue diseases positive for APLA (aCL and LA).

3. To determine the association between clinical manifestations and APLA.

\section{Subjects and Methods}

This is a hospital based, analytical cross-sectional study, was conducted among two hundred and four patients who were diagnosed with connective tissue disorders like Systemic Lupus Erythematosus, Mixed Connective Tissue Disease (MCTD), Sjogrens syndrome and systemic 
sclerosis based on clinical criteria and laboratory parameters obtained. The updated Sapporo APS Classification or Sydney Classification (2006) for clinical criteria and laboratory criteria were used to classify the patients. 9 The study was started after obtaining clearance from the Institutional Ethics Committee (IEC) and a written consent was taken from the patients. Those who had given written consent to participate in the study were included. A detailed history taking and clinical examination was performed. All the patients were subjected to undergo routine blood tests mainly complete hemogram with peripheral smear, renal function tests, urine routine examination, liver function tests, Coomb's test, anti- nuclear antibody testing, extracted nuclear antigen testing and a skin biopsy. A Chest X-ray, Electrocardiogram (ECG), Echocardiogram (2-D Echo), and Pulmonary Function Tests (PFT) were performed on the patients. A computed tomography brain (CT-Brain) and Doppler study of lower limbs was performed among selected indicated patients. APLA test (which included anticardiolipin antibody and LA tests) was performed as a baseline test to all the patients and patients who were found to be positive for the test, a repeat of the test was performed after 12 weeks as per the international consensus statement in revised classification criteria for definite APS. To detect LA an automated coagulation analyzer was used which was based on coagulation tests and test was considered positive if the results showed $>1.2 \mathrm{~s}$ (normal value is less than or equal to $1.2 \mathrm{~s}$ ). To detect aCL, ELISA method was done and it was considered positive if results showed $>12 \mathrm{u} / \mathrm{ml}$ (normal value is less than or equal to $12 \mathrm{u} / \mathrm{ml}$ ).

\section{Results}

In the present study two hundred and four patients were included and [Table $1 \&$ Figure 1] show 54 p.c (110) were diagnosed with SLE followed by 18.3 p.c (38) were diagnosed with MCTD, 15.7 p.c (32) were diagnosed with systemic sclerosis and 12 p.c (24) were diagnosed with Sjogrens syndrome. In Table-2 the APLA positive patients with SLE were 73.3 p.c (23) subjects followed by 13.35 (4) p.c in systemic sclerosis and 13.35 p.c (4) MCTD. The aCL positive patients with SLE 5.5 p.c (9) followed by 3.7 p.c (2) in systemic sclerosis and MCTD each. The LA positive patients with SLE 9.5 p.c (14) followed by 3.7 p.c (2) in systemic sclerosis and MCTD each. In Table-3 the percentage of APLA positivity and APLA negativity patients with neurological manifestations, hemolytic anemia, leg ulcers, thrombocytopenia, proteinuria and serositis were overlapping between APLA and connective tissue disorders had been tabulated with statistical values. The patients who were with above clinical manifestations and positive for APLA belonged to the SLE group.

Table 1: Distribution Of Patients Based On Diagnosis

\begin{tabular}{|l|l|l|}
\hline Diagnosis & Number of patients & Percentage of patients \\
\hline SLE & 110 & 54 \\
\hline MCTD & 38 & 18.3 \\
\hline Systemic sclerosis & 32 & 15.7 \\
\hline Sjogrens syndrome & 24 & 12 \\
\hline Total & 204 & 100 \\
\hline
\end{tabular}

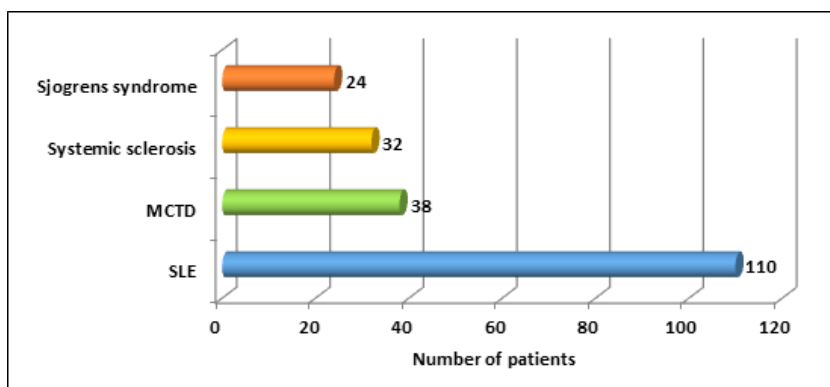

Figure 1: Distribution of Patients Based on Various Etiologies

Table 2: Connective Tissue Etiologies and Percentage of Positive APLA, ACL and LA among the Patients

\begin{tabular}{|l|l|l|l|}
\hline Etiology & $\begin{array}{l}\text { Percentage of } \\
\text { APLA } \\
\text { Positive } \\
\text { Patients }\end{array}$ & $\begin{array}{l}\text { aCL Positive } \\
\text { Patients }\end{array}$ & $\begin{array}{l}\text { LA Positive } \\
\text { Patients }\end{array}$ \\
\hline SLE & $73.3(23)$ & $5.5(9)$ & $9.5(14)$ \\
\hline $\begin{array}{l}\text { Systemic } \\
\text { sclerosis }\end{array}$ & $13.35(4)$ & $3.7(2)$ & $3.7(2)$ \\
\hline MCTD & $13.35(4)$ & $3.7(2)$ & $3.7(2)$ \\
\hline
\end{tabular}

Table 3: SLE Patients with Clinical Manifestations and

Percentage of Positive \& Negative APLA among Patients

\begin{tabular}{|l|l|l|l|}
\hline $\begin{array}{l}\text { Clinical } \\
\text { manifestatio } \\
\text { ns }\end{array}$ & $\begin{array}{l}\text { Percentage of } \\
\text { APLA Positive } \\
\text { Patients }\end{array}$ & $\begin{array}{l}\text { Percentage of } \\
\text { APLA Negative } \\
\text { Patients }\end{array}$ & $\begin{array}{l}\text { p- } \\
\text { Val } \\
\text { ue }\end{array}$ \\
\hline $\begin{array}{l}\text { Neurologic } \\
\text { manifestations }\end{array}$ & 72.7 & 27.3 & 0.01 \\
\hline $\begin{array}{l}\text { Hemolytic } \\
\text { anemia }\end{array}$ & 62.3 & 37.7 & $\begin{array}{l}0.00 \\
1\end{array}$ \\
\hline $\begin{array}{l}\text { Leg } \\
\text { ulcerations }\end{array}$ & 87.2 & 12.8 & NS \\
\hline $\begin{array}{l}\text { Thrombocytop } \\
\text { enia }\end{array}$ & 72.7 & 27.3 & NS \\
\hline Serositis & 25.8 & 74.2 & NS \\
\hline Proteinuria & 19.6 & 80.4 & NS \\
\hline
\end{tabular}

\section{Discussion}

The vessel wall integrity will be maintained by antiphospholipid antibodies which are directed against cell membrane phospholipids. Manifestations like neurological, hemolytic anemia, thrombocytopenia, leg ulcerations, proteinuria and serositis are overlapping in APLA and connective tissue disorders most importantly among patients with SLE, which cause a diagnostic dilemma. In a study conducted by Cervera R and Piette JC et al in the year 2002, APLA positivity was found to be among 36.2 p.c in the SLE group. ${ }^{[10]}$ In the present study, 73.3 p.c of patients with positive APLA belonged to the SLE group. In this study about 87.2 p.c SLE patients were suffering from leg ulcerations had a positive APLA. Similar to the study by Yoon KH et al., 49.3 p.c of APLA positive SLE had neurological manifestations. ${ }^{[11]}$ In the present study, 72.7 p.c of APLA positive SLE patients had neurological manifestations. In a study conducted by Nesher $\mathrm{G}$ et al, 89 p.c SLE patients presented with thrombocytopenia and there was a statistically significant association between thrombocytopenia and APLA positivity. ${ }^{[12]}$ Similarly in the present study, 72.7 p.c with thrombocytopenia were APLA 
positive but there was no statistically significant association between thrombocytopenia and SLE. In the present study serositis, leg ulcerations, thrombocytopenia and proteinuria were overlapping between SLE and APLA, but there was no statistically significant association between these manifestations and APLA positivity.

\section{Conclusion}

Anti-phospholipid antibodies and SLE have overlapping clinical manifestations. APLA can complicate SLE further which results in higher morbidity rates. So, it is important to detect APLA for early diagnosis and prevention of lifethreatening complications among patients suffering from connective tissue disorders most importantly SLE.

\section{References}

1. Bataille S, Burtey S, Decourt A, Frere C, Henneuse A, Aillaud MF, Morange P, Bardin N, Duval A, Sallee M, Jourde-Chiche N. Antiphospholipids antibodies and hemodialysis: a frequent association linked to arteriovenous fistula thrombosis. Nephrologie \& therapeutique. $2015 \mathrm{Feb}$;11(1):27-33.

2. Wilson WA, Gharavi AE, Koike T, Lockshin MD, Branch DW, Piette JC, Brey R, Derksen R, Harris EN, Hughes GR, Triplett DA. International consensus statement on preliminary classification criteria for definite antiphospholipid syndrome: report of an international workshop. Arthritis \& Rheumatism: Official Journal of the American College of Rheumatology. 1999 Jul;42(7):1309-11.

3. Jerrold S, Levine D, Branch W, Rauch J. The antiphospholipid syndrome. N Engl J Med. 2002 Mar;346(10):752-63.
4. Chi HS. Recent advances in the diagnosis of antiphospholipid syndrome. International journal of hematology. 2002 Mar 1;76(2):4751.

5. Barbui T, Berrettini M, Ferrini PL, Finazzi G, Galli M, Ciavarella N, Schiavoni M, Palareti G, Marongiu F, Muleo G, Ferrari L. Thrombosis and thrombocytopenia in Antiphospholipid Syndrome (idiopathic and secondary to SLE)-1 st report from the Italian Registry.

6. Harris EN. Clinical and serological features of the'antiphospholipid syndrome'. Brit J Rheumatol. 1987;26:19.

7. Mackworth-Young CG, Loizou S, Walport MJ. Primary antiphospholipid syndrome: features of patients with raised anticardiolipin antibodies and no other disorder. Annals of the rheumatic diseases. 1989 May 1;48(5):362-7.

8. Furmańczyk A, Komuda-Leszek E, Gadomska W, Windyga J, Durlik M. Catastrophic antiphospholipid syndrome. Pol Arch Med Wewn. 2009 Jun;119:427-30.

9. Bustamante JG, Singhal M. Antiphospholipid Syndrome (Antiphospholipid Antibody Syndrome, APS, APLS) [Updated 2018 Dec 29]. In: StatPearls [Internet]. Treasure Island (FL): StatPearls Publishing; 2019 Jan-. Available from: https://www.ncbi.nlm.nih.gov/books/NBK430980/.

10. Cervera R, Piette JC, Font J, Khamashta MA, Shoenfeld Y, Camps MT, Jacobsen S, Lakos G, Tincani A, Kontopoulou- Griva I, Galeazzi M. Antiphospholipid syndrome: clinical and immunologic manifestations and patterns of disease expression in a cohort of 1,000 patients. Arthritis \& Rheumatism: Official Journal of the American College of Rheumatology. 2002 Apr;46(4):1019-27.

11. Yoon KH, Fong KY, Sivalingam P, Koh DR, Ng SC, Lim TC, Kassim S. Antiphospholipid syndrome in Asians: clinical manifestations, serological markers and outcome of the National University of Singapore/National University Hospital antiphospholipid cohort. APLAR Journal of Rheumatology. 2003 Oct;6(2):128-36.

12. Nesher G, Hanna VE, Moore TL, Hersh M, Osborn TG. Thrombotic microangiopathic hemolytic anemia in systemic lupus erythematosus. In Seminars in arthritis and rheumatism 1994 Dec 1 (Vol. 24, No. 3, pp. 165-172). WB Saunders.

Copyright: ( $)$ the author(s), 2019. It is an open-access article distributed under the terms of the Creative Commons Attribution License (CC BY 4.0), which permits authors to retain ownership of the copyright for their content, and allow anyone to download, reuse, reprint, modify, distribute and/or copy the content as long as the original authors and source are cited.

How to cite this article: Reddy KR, Lakshmi VSS. An Association between Anti- Phospholipid Antibodies and Connective Tissue Diseases. Asian J. Med. Res. 2019;8(3):DT01-DT03.

DOI: dx.doi.org/10.21276/ajmr.2019.8.3.DT1

Source of Support: Nil, Conflict of Interest: None declared. 